\title{
Vaginal Cancer Pathologic TNM Finding v7
}

National Cancer Institute

\section{Source}

National Cancer Institute. Vaginal Cancer Pathologic TNM Finding v7. NCI Thesaurus.

Code C89456.

A pathologic finding about one or more characteristics of vaginal cancer, following the rules of the TNM AJCC V7 classification system. 